\title{
Bigarren Hezkuntzako ikasle eta irakasle talde baten diskurtsoa eta praktika informazio digitala bilatzeko, ebaluatzeko eta hautatzeko orduan
}

\author{
Searching, evaluating and selecting information: \\ discourses and practices of secondary students and teachers \\ Maite López Flamarique, Txema Egaña Osa* \\ Nafarroako Unibertsitate Publikoa \\ Mondragon Unibertsitatea
}

LABURPENA: Azterketa honetan, Bigarren Hezkuntzako ikasle eta irakasleek ikasgelan informazio digitala bilatzeko, ebaluatzeko eta hautatzeko orduan erabiltzen dituzten diskurtsoa eta praktika alderatu nahi dira. Kasu-azterketa bat izanik, hainbat iturritako datuak triangelatu dira (eztabaida-taldeetakoak, eskoletakoak eta aurrez aurreko elkarrizketetakoak). Emaitzen arabera, ikasleek badute interesa ikasgelan Internetera konektatuta lan egiteko, baina zailtasunak dituzte bideo eta grafikoak interpretatzeko, eta ez dute kontuan hartzen nor diren testuen egileak. Bestalde, irakasleek ikusten dute beren rola zalantzan jartzen dela, eta uzkur jokatzen dute aldaketaren aurrean. Ondorioetan ikusiko dugunez, informazioa alfabetizatzeko didaktika bat behar da, ikasleen praktika eta interes errealetatik abiatuko dena. Horretarako, irakasleen rola eta sinesmenak aldatu behar dira.

GAKO-HITZAK: informazioa bilatzea, informazioa ebaluatzea, IKTak, irakasleak, ikasleak.

\begin{abstract}
This study seeks to contrast the discourse and practice of students and secondary school teachers when searching, evaluating and selecting digital information in a secondary classroom. This is a case study that has used a multi-source data triangulation (discussion groups, class registration and self-report interviews). The results indicate the interest of the students to work connected to the internet in the classroom, although it is observed that it has difficulties in the interpretation of videos and graphics, and that it does not take into account the authorship of the text. On the other hand, teachers have questioned their role and show reluctance to change. The conclusions suggest that a didactic of informational literacy is necessary based on the real practices and interests of the students. For this, a change of role and beliefs of the teaching staff is required.
\end{abstract}

KEYWORDS: information search, information evaluation, ICT, teachers, students.

* Harremanetan jartzeko / Corresponding author: Txema Egaña Osa. Mondragon Unibertsitatea. Humanitate eta Hezkuntza Zientzietako Fakultatea. Dorleta auzoa, z/g. 20540 - Eskoriatza -tegana@mondagon.edu - https://orcid.org/0000-0002-3859-5279

Nola aipatu / How to cite: López Flamarique, Maite; Egaña Osa, Txema. (2019). «Bigarren Hezkuntzako ikasle eta irakasle talde baten diskurtsoa eta praktika informazio digitala bilatzeko, ebaluatzeko eta hautatzeko orduan»; Tantak, 31(1), 103-120. (https://doi.org/10.1387/tantak.20407).

Jasotze-data: 2018/11/30 Onartze-data: 2018/02/07.

ISSN 0214-9753 - elSSN 2444-3581 / (c) 2019 UPV/EHU

(c) (i) Obra hau Creative Commons Atribución 4.0 Internacional-en lizentziapean dago 
Maite López Flamarique, Txema Egaña Osa

\section{SARRERA}

Mundu aldakor batean bizi gara, desberdintasun sozioekonomiko handiekin, eta informazioa egoki erabiltzea funtsezkoa da garapenerako (Unesco, 2005). Testuinguru horretan, oinarrizkoa da derrigorrezko eskola-prestakuntzaren zikloa amaitzen duten pertsonek eta, oro har, herritar guztiek gaitasuna izatea informazioa erabiltzeko, bilatzeko eta hautatzeko (Adell \& Castañeda, 2012). Hori dela eta, azken urteetan, informazio-kudeaketarekin loturiko konpetentziek gero eta garrantzi handiagoa dute (Area-Moreira \& Pessoa, 2012). Ildo horretan, informazioaren eta datuen erabileraren alfabetizazioa da Europako Batzordearen The Digital Competence Framework for Citizens txostenean jasotzen diren bost konpetentzietako bat (Carretero, Vuorikari \& Punie, 2017).

Hala eta guztiz ere, beste egile batzuen lanak irakurriz ikusten da Bigarren Hezkuntzako ikasleek ez dutela gaitasun digitalik (Moreno Mínguez, 2013; Watkins, Engel \& Hastedt, 2015). Mundu konektatu batean hazi arren konpetentzia digitala bermatzen ez bada, eskola eta derrigorrezko hezkuntzaren aldia dira konpetentzia hori garatzeko berezko espazioak. Gure inguruneko hezkuntza sistemetan halaxe ulertu da, eta konpetentzia digitalaren garapena curriculumetako konpetentzia gakoetako bat balitz bezala hartzen da. Alfabetatze kontzeptua bera aldatu egin da, eta gaur egun ezinbestekoa da derrigorrezko prestakuntza zikloa amaitzen duten pertsonak konpetente izatea informazioaren kudeaketan, bilaketan, hautaketan eta erabileran (Area-Moreira \& Pessoa, 2012).

Testuinguru horretan, Bigarren Hezkuntzako ikasleek uste dute Internet ongi erabiltzen jakitea lagungarria izango zaiela etorkizunean profesional hobeak izateko, eta iruditzen zaie ikaskuntza prozesuan Internet erabiltzea interesgarriagoa dela, baina ez nahitaez entretenigarriagoa (Gialamas, Nikolopoulou \& Koutromanos, 2013). Hala eta guztiz ere, Campos Martínezek (2015) ohartarazi du zenbait ikaslek diskurtso ezkorrak dituztela eskolan IKTak erabiltzeari buruz, helduen pentsaeraren eraginez segur aski.

Praktikari dagokionez, gazte gehienek badute konfiantza Interneten informazioa bilatzeko dauzkaten trebetasunetan, nahiz $\% 2 \mathrm{k}$ bakarrik erabiltzen dituen pentsamendu kritikorako trebetasunak (Watkins, Engel \& Hastedt, 2015). Horregatik, egileek ondorioztatu dute arrakala bat dagoela IKTen erabileraren eta haien erabilera kritikoaren artean. Zenbaitetan, ikasleei iruditzen zaie irakasleek baino gaitasun handiagoa dutela (Egaña, $\mathrm{Zu}$ berogoitia \& Pavón, 2012; Fraga Varela \& Gewerc Barujel, 2013). Ros eta Ferradasen ikerketa baten arabera (2013), irakasleen ia \% 60k uste du ikasleek hobeto erabiltzen dituztela IKTak.

Beren eskola-jardunean, ikasleek askotan egin behar diote aurre Interneten informazioa bilatzeko, hautatzeko eta erabiltzeko erronkari (Pow \& Li, 2015), eta hori bereziki zaila egiten zaie Bigarren Hezkuntzako ikasleei (Eagleton, Guinee \& Langlais, 2003). Ikasleek badakite nolako ahale- 
gina eskatzen duen informazioa ebaluatzeak eta hautatzeak, eta irakasleen eskakizunen eta ikasleen beren interes pertsonalen arabera egiten dute lan (Egaña, Zuberogoitia, Pavón \& Brazo, 2012). Askotan, arazoak dituzte bila dabiltzan informazioa aurkitzeko (Egaña, Zuberogoitia et al., 2012), eta zaila egiten zaie iritziak eta datuak bereiztea (Kim \& Sin, 2011). Bereziki zaila iruditzen zaie hainbat iturritako informazioa erabiltzea eta edukiak alderatzea (Hatlevik \& Hatlevik, 2018). Valverde- Crespok eta GonzálezSánchezek (2016) ondorioztatu dute ikasleek Wikipedia erabiltzen dutela lehen iturri gisa, oso eskuragarria delako eta edozein gairi buruzko informazioa dakarrelako; ikasleek diote ez dutela arazorik entziklopedia birtualaren hizkuntza eta edukia ulertzeko.

Agerikoa dirudi ikasleek irakasleen babesa eta jakintza behar dituztela informazioa eraginkortasunez eta kritikotasunez erabiltzen ikasteko (Hatlevik \& Hatlevik, 2018). Powk eta Lik dioten bezala (2015: 453), irakasleek laguntza eman behar liekete ikasleei beren ikaskuntza prozesua garatu dezaten. Ikasgelan IKTak adierazgarritasunez erabiltzea («high-level») praktika konstruktibistekin lotzen da (Ertmer, 2005), eta horrek irakasleen rola aldatzea dakar: prestakuntza prozesuan autoritatea eta kontrola izatetik «erreferente kualifikatu» izatera igarotzen dira (Plaza De La Hoz, 2018). Izan ere, zenbait azterketatan ondorioztatu da (Gil-Flores, Rodríguez-Santero \& Torres-Gordillo, 2017; Tirado-Morueta \& Aguaded Gómez, 2014; Tondeur, Van Braak, Ertmer \& Ottenbreit-Leftwich, 2017) ikasleei begirako praktika pedagogiko konstruktibistaz baliatzen diren irakasleek gehiago erabiltzen dutela teknologia ikasgelan.

Baliabide teknologikoak izateak ez du bermatzen ikas jarduera berritzaileak erabiliko direnik, eta ikusi da askotan ordenagailua erabiltzen dela lehen ere ordenagailurik gabe egiten ziren jardueren antzekoak egiteko (Sancho Gil, Hernandez, 2018; Watkins et al., 2015) eta oraindik asko falta dela IKTak benetan ikasgelan txertatzeko (Ros \& Ferradas, 2013). Espainiako ikastetxeetan IKTen erabilerari buruz egindako lehen ikerketen arabera, irakasleek ez zituzten beren hezkuntza jarduerak ia aldatzen ikasgelan ekipamendu teknologikoa sartu arren (Aguaded Gómez \& Tirado Morueta, 2010; Coll, Mauri Majós \& Onrubia Goñi, 2008). Teaching and Learning International Study - Talis ikerketako datuen azterketa baten arabera (Gil-Flores, Rodriguez-Santero, Torres-Gordillo, 2017), baliabide teknologiko gutxi erabiltzen da ikasgeletan: irakasleen \% 19,6k dio ez dituela erabiltzen edo oso gutxitan erabiltzen dituela IKTak eskolak emateko, eta $\% 43,4 \mathrm{k}$, berriz, noizbehinka erabiltzen dituela. Ikerketa berriagoetan, berretsi da irakasleak bere irakasle jardunarekin uztartzen duela teknologia; dena den, baliabide teknologikoek ez dituzte baliabide tradizionalak ordezkatzen, baizik eta batera erabiltzen dira, eta testuliburua da oraindik ere baliabide erabiliena (Area-Moreira, Hernández-Rivero \& Sosa-Alonso, 2016). Zenbait egilek (Ertmer \& Ottenbreit-Leftwich, 2010) uste dute ezinbestekoa dela informazioaren eta komunikazioaren teknologiak (IKTak) 
erabiltzea kalitatezko irakaskuntza bat eskaintzeko: «Teaching is not effective without the appropriate use of information and communication technologies (ICT) resources to facilitate student learning» (2010: 255).

Lanon arabera, garrantzitsua da irakasleek prestakuntza jasotzea IKTak beren zeregin didaktikoetan adierazgarritasunez txerta ditzaten. Prestakuntza horretan, beharrezkoa da oinarrizko prestakuntza sendoa ematea hardwarearen eta softwarearen erabilerari buruz (Hew \& Brush, 2007), eta orobat garrantzitsua da teknologia pedagogikoki erabiltzen eta IKTak eskoletan eraginkortasunez txertatzen ikastea (Altuna Urdin, 2011; Area-Moreira, Cepeda, González Salamanca \& Sanabria, 2010).

Dena den, ikasgelan IKTak erabiliz gero dinamika aldatzen dela eta horrek berrikuntza pedagogikoan laguntzen duela. Aguaded Gomezek eta Tirado Moruetak (2010) adierazi dute ikasgelan teknologiak erabiltzeak «ate bat ireki» duela irakaskuntza aktiboagoa eta lankidetzara bideratuagoa izan dadin, eta Domingo Coscollolak eta Fuentes Agustík (2010) berretsi dute ekarpena egiten diola berrikuntza metodologikoari. Gai honi buruz idatzitakoaren gainean begirada kritikoa ipiniz (Tondeur, Van Braak, Ertmer, Ottenbreit-Leftwich, 2017), ohartzekoa da ezen ikasgelan teknologia erabiliz gero irakasleek gehiago esperimentatzen dutela eta hezkuntza eredu konstruktibistagoak eta ikasleengan zentratuagoak erabiltzen dituztela. Ildo beretik, beste ikerketa batek hauxe dio: «Irakasleek IKTak beren jardunean nola txertatu birplanteatu behar dute, eta, ondorioz, berrikuntzak egiten dituzte» (Area-Moreira, Hernández-Rivero, Sosa-Alonso, 2016: 85). Nolanahi ere, aldaketak poliki gertatzen ari dira. Ertmerrek dio (2005) garrantzitsua dela IKTak progresiboki txertatzea, irakaslearen premia eta estilo didaktikoetara egokituz, hark konfiantza har dezan. Altuna Urdinek, berriz, proposatzen du gogoeta bat egin beharra dagoela (2011).

Zenbait egilek diotenez, irakasleek beren praktika pedagogikoarekiko koherentziaz erabiltzen dute teknologia (Area-Moreira et al., 2016; Kim, Kim, Lee, Spector \& Demeester, 2013; Lawrence \& Usman, 2018), eta azterketa berriagoetan ondorioztatu da ikasleei begirako praktika pedagogiko konstruktibistaz baliatzen diren irakasleek gehiago erabiltzen dutela teknologia ikasgelan (Gil-Flores et al., 2017; Tirado Morueta \& Aguaded Gómez, 2014; Tondeur et al., 2017).

Beharrezkoa da jakitea zer gertatzen den irakaskuntza eta ikaskuntza prozesuetan IKTak erabiltzen direnean (Area-Moreira, Cepeda, González-Salamanca, Sanabria, 2010; Coll, Mauri Majós, Onrubia Goñi, 2008). Mama eta Hennessy-k (2013) irakasle batzuen iritzien eta praktiken arteko desadostasunak behatu zituzten; izan ere, nahiz eta teknologia erabiltzen duten beren bizitza pertsonalean eta jarrera oso positiboa erakusten duten ikasgelan teknologiaren erabilerari dagokionez, irakasle hauek gutxitan erabili zuten teknologia gelan.

Hori dela eta, Cambraren lana abiapuntutzat harturik (2013), ikerketa honetan, batetik, irakasleen diskurtsoan eta praktikan dauden tentsioak 
identifikatu nahi dira, eta, bestetik, irakasle eta ikasleen diskurtsoa eta praktika alderatu (Gil-Flores et al., 2017). Hala, aztertuko dugu zer harreman eraikitzen diren jarduera bat egiteko informazioa Interneten bilatzean, ebaluatzean eta hautatzean. Helburu horrekin loturik, honako galdera hauei erantzun nahi genieke: (a) Zer diskurtso eta praktika dituzte ikasleek ikasgelan informazio digitala bilatzean, ebaluatzean eta hautatzean?; (b) zer diskurtso eta praktika dituzte irakasleek ikasgelan informazio digitala bilatzean, ebaluatzean eta hautatzean?

\section{METODOLOGIA}

Ikerketa honetan, metodologia kualitatiboa erabili dugu, hau da, hainbat iturritako datuak triangelatuz (Rodríguez Ruiz, 2005), emaitza baliagarriagoak lortu nahi izan ditugu. Zenbait teknika kualitatibo erabili dira: eztabaida taldeak ikasle eta irakasleekin; eskola saioen eta hiru ikasle bikotek ordenagailuan egindako lanaren erregistroa; eta aurrez aurreko elkarrizketak, banakakoak zein taldekakoak (Thereau, 2010). Guztiak irakaskuntza eta ikaskuntza prozesuaren une jakin batzuetan egin dira.

Ikerketa Nafarroako hegoaldeko DBHko institutu batean egin da; izan ere, ikastetxe hori aukeratu zen Hizkuntza Saileko irakasleek sekuentzia didaktikoen bitartez antolaturiko proiektuekin lan egiten dutelako neurri handi batean. Ildo horretan, informazioa bilatzeko, ebaluatzeko eta hautatzeko estrategiak ez dira irakatsi behar linealki eta ondoz ondo, baizik eta proiektu didaktiko baten barruan txertatuta, ikasleak egiazko premia izan dezan Internetera jotzeko informazio bila (Kuiper, Volman \& Terwel, 2009).

2014-2015 ikasturtean bildu ziren datuak, eta, garai hartan, ikastetxeak 1.150 ikasle eta 103 irakasle zituen. Ikastetxeko ikasgela guztietan bazegoen ordenagailu eramangarri bat, Interneterako sarbidea kable bidez eta proiektagailu bat. Horretaz gainera, ikastetxean baziren hiru informatika gela eta mahai gaineko 16 ordenagailu haietariko bakoitzean, eta hiru teknologia ikasgela, eta 16 ordenagailu eramangarri haietariko bakoitzean (ekipo guztiek kable bidezko konexioa zeukaten). Informatika eta Teknologia ikasgaiak ikasgela horietan ematen ziren. Gainerako irakasleek bazuten aukera ikasgelok erabiltzeko, Informatikako eta Teknologiako irakasleek erabiltzen ez zituzten orduetan.

Gaztelania eta Literaturako zortzi irakaslek eta DBHko 4. mailako 24 ikaslek parte hartu zuten ikerketan, nahiz ez denek modu berean. Zortzi irakasleek eztabaida talde batean parte hartu zuten hasieran, eta han erabaki zen ikerketa DBHko 4. mailako proiektu batean zentratzea. Zehazki, ikasleek dokumentazioa aurkitu behar zuten Interneten informazioa bilatuz, kazetaritzako erreportaje bat egiteko. Aurreko urteetan ere erabilia zuten baliabide didaktiko hori, baina informazioa Interneten bilatzea etxerako 
lan gisa planteatu zen, irakaslearen laguntzarik gabe. DBHko 4. mailako lau irakaslek baliabide didaktiko berria eraman zuten ikasgelara, prestakuntza prozesu batean parte hartu eta sekuentzia didaktikoa moldatu ondoren (Dolz \& Gagnon, 2010). Hala, informazioaren plangintza egiteko, bilatzeko, ebaluatzeko eta hautatzeko estrategiak txertatu zituzten.

1. taula

\section{Erabilitako datuak biltzeko teknikak}

\begin{tabular}{l|l}
\hline Datuak biltzeko teknikak & \multicolumn{1}{c}{ Deskripzioa } \\
\hline GDP & $\begin{array}{l}\text { Hizkuntza departamentuko irakasleekin egindako ezta- } \\
\text { baida-taldea, esku-hartze didaktikoa baino lehen. Ber- } \\
\text { tan arakatu ziren beren usteak eta praktikak IKTak ge- } \\
\text { lan erabiltzerakoan. }\end{array}$ \\
\hline GDAi & $\begin{array}{l}\text { Ikasleekin egindako eztabaida-taldea esku-hartze didak- } \\
\text { tikoa baino lehen. Bertan arakatu ziren beren usteak eta } \\
\text { praktikak IKTekiko gela barruan eta gelatik kanpo. }\end{array}$ \\
\hline GDAf & $\begin{array}{l}\text { Ikasleekin egindako eztabaida-taldea esku-hartze di- } \\
\text { daktikoaren ondoren. Praktika erabili zituzten estrate- } \\
\text { gien inguruan aritu ziren. }\end{array}$ \\
\hline TA & $\begin{array}{l}\text { Ikasleen hiru bikoteren arteko elkarrekintza, gelan egin } \\
\text { zuten lana burutzeko. }\end{array}$ \\
\hline AC & $\begin{array}{l}\text { Irakaslearen autokonfrontazioa, bere irakasle jarduera } \\
\text { bideoz jaso zen. }\end{array}$ \\
\hline ACG & $\begin{array}{l}\text { Talde autokonfrontazioa. Lau irakaslek parte hartu zu- } \\
\text { ten, beretako baten irakasle-jarduera jasotzen duen bi- } \\
\text { deoaren ikusketan. }\end{array}$ \\
\hline
\end{tabular}

Ikasleekin informazioa bilatzea, ebaluatzea eta hautatzea landu zuten DBHko 4. mailako irakasleetako baten 6 saio erregistratu ziren, eta, saio horietan, Camtasia programa erabili zen, hiru ikasle bikotek ordenagailuan egindako lana gordetzeko. Sei ikasle horiek amaierako talde eztabaidan parte hartu zuten. Eskolen grabazioekin eta hiru ikasle bikoteen lanarekin, bideo bat editatu zen; gero, aurrez aurreko elkarrizketak egin ziren grabazioetan parte hartu zuen irakaslearekin (banakakoa) eta sekuentzia didaktikoa ikasgelara eraman zuten DBHko 4. mailako lau irakasleekin (taldekakoa). Teknika horren bidez, irakasleek bideoa ikusi eta gogoeta egin dezakete beren jardunaz. 
Datuen analisia egiteko, bai eztabaida taldeetakoak, bai ikasgelako jardueretakoak eta aurrez aurreko elkarrizketetakoak, informazioa alfabetizatzeko konpetentzia estandarrak erabili ditugu (Association of College \& Research Libraries, ACRL, 2000). ACRLk 5 estandar definitu ditu, eta, haien barruan, 23 adierazle. Gure analisian, kontuan izan genituen lehen hiru arauak eta haien estandarrak, hau da, gure ikerketaren xedearekin loturikoak (ikus 2. taula). Zenbait irakurketaren ondotik, alfabetizazio arauak eta estandarrak irakasleen jardunarekin erlazionatu, eta analisirako kategoriak ezarri ziren (berdez, 2. taulan). Bestalde, ikasleen jardunarekin loturiko zenbait kategoria eta dimentsio kodetzeko, sailkatzeko eta aurkitzeko prozesu bat egin zen (urdinez, 2. taulan); kategoria eta dimentsiook ez daude ACRLren arau eta estandarretan, eta irakasleen jardunetik urruti geratzen ziren. Era horretan, analisirako esparru bat lortu genuen, ikasgelako jardun didaktikora areago hurbiltzeko eta hura hobeto ulertzeko.

2. taula

Analisirako kategoriak, informazioa alfabetizatzeko arau eta estandarren araberakoak eta irakasleen lanaren eta ikasleen jardueraren arabera moldatuak

ACRLren informazioa alfabetizatzeko arau eta estandarrak (ACRL, 2000)
ACRLren estandarrak irakasleen jardunean zehaztuz lorturiko analisi kategoriak, ikerlariek definitutakoak. Kategoria sortu berriak, ikerlariek definitutakoak datuen analisietatik.

1. ARAUA: ikaslea gai da zehazteko nondik datorren eta zer maila duen behar duen informazioak.

\begin{tabular}{l|l}
\hline $\begin{array}{l}\text { Definitzen du eta artikulatzen du zer } \\
\text { informazio behar duen. }\end{array}$ & $\begin{array}{l}\text { Lanerako gai bat aukeratzea. } \\
\text { Bilaketaren helburuak eta gaiari bu- } \\
\text { ruzko galderak identifikatzea. } \\
\text { Interesik eza gaiari buruz. }\end{array}$ \\
\hline $\begin{array}{l}\text { Identifikatzen ditu zenbait informazio } \\
\text { mota eta formatu. }\end{array}$ & $\begin{array}{l}\text { Lehen mailako iturriak (elkarrizketa) } \\
\text { eta bigarren mailakoak (Internet, doku- } \\
\text { mentuak) identifikatzea eta bereiztea. } \\
\text { Ikus-entzunezko informazioa lehenes- } \\
\text { tea. }\end{array}$ \\
\hline $\begin{array}{l}\text { Birplanteatzen du zer informazio behar } \\
\text { duen. }\end{array}$ & Bilaketaren helburuak berrikustea. \\
\hline
\end{tabular}


2. ARAUA: ikaslea gai da eskaturiko informazioa efikaziaz eta efizientziaz lortzeko.

\begin{tabular}{l|l}
\hline $\begin{array}{l}\text { Aukeratzen ditu informazioa berresku- } \\
\text { ratzeko sistema egokiak. }\end{array}$ & $\begin{array}{l}\text { Google bilatzailea erabiltzea. } \\
\text { Beste bilatzaile batzuk erabiltzea } \\
\text { (YouTube...). }\end{array}$ \\
\hline $\begin{array}{l}\text { Praktikan jartzen ditu bilaketak egiteko } \\
\text { estrategia eraginkorrak. }\end{array}$ & $\begin{array}{l}\text { Hitz gako egokiak erabiltzea. } \\
\text { Bilaketa Aurreratua erabiltzea. } \\
\text { Interesik ez Interneten informazioa bi- } \\
\text { latzeko. }\end{array}$ \\
\hline Fintzen du bilaketa estrategia. & Hitz gakoak gehitzea edo birformulatzea. \\
\hline
\end{tabular}

3. ARAUA: ikasleak kritikoki ebaluatzen ditu informazioa eta informazio iturriak, eta bere ezagutza oinarrietan eta balio sisteman txertatzen du hautaturiko informazioa.

\begin{tabular}{l|l}
\hline Laburtzen ditu ideia nagusiak. & $\begin{array}{l}\text { Testua irakurtzea eta ideia nagusiak } \\
\text { hautatzea. }\end{array}$ \\
\hline $\begin{array}{l}\text { Aplikatzen ditu informazioa eta haren } \\
\text { iturriak ebaluatzeko irizpideak. }\end{array}$ & $\begin{array}{l}\text { Argitasuna eta ulergarritasuna ebaluatzea. } \\
\text { Informazioaren baliagarritasuna eba- } \\
\text { luatzea. } \\
\text { Egiletza eta fidagarritasuna ebaluatzea. } \\
\text { Ikuspegi edo aurreiritzi ideologikoa } \\
\text { ebaluatzea. } \\
\text { Asmoa ebaluatzea. } \\
\text { Gaur egungoa den ala ez ebaluatzea. } \\
\text { Interesik ez informazioa eta haren itu- } \\
\text { rriak ebaluatzeko. }\end{array}$ \\
\hline $\begin{array}{l}\text { Alderatzen ditu ezagutza berriak eta } \\
\text { aurrekoak. }\end{array}$ & $\begin{array}{l}\text { Ondorioak ateratzea lorturiko informa- } \\
\text { ziotik abiatuta. } \\
\text { Hainbat iturritako informazioa alderatzea. }\end{array}$ \\
\hline $\begin{array}{l}\text { Zehazten du zer eragin duen ezagutza } \\
\text { berriak bere balioetan. }\end{array}$ & $\begin{array}{l}\text { Aurkitutako ikuspegiak kontuan hartzen } \\
\text { dituen ala baztertzen dituen erabakitzea. } \\
\text { Edukien eragin emozionala. }\end{array}$ \\
\hline $\begin{array}{l}\text { Baliozkotzat jotzen du iritzi trukeen bi- } \\
\text { tartez ulertzea. }\end{array}$ & $\begin{array}{l}\text { Pareen arteko interakzioan informazioa } \\
\text { ulertzen ikastea. } \\
\text { Ikaskidearekin ez parte hartzea edo ha- } \\
\text { ren lana oztopatzea. }\end{array}$ \\
\hline $\begin{array}{l}\text { Lanarekin zerikusirik ez duten elkarriz- } \\
\text { keta edo bilaketetan denbora galtzea. }\end{array}$ \\
\hline
\end{tabular}


Lan saioen grabazioak transkribatu ondoren, grabazioak analisi unitatetan banatu genituen, analisia errazteko asmoz. Azkenik, hurrengo atalean aurkeztuko ditugun emaitzetara iristeko, aurrez aurreko elkarrizketetan eta ikasle-irakasleen arteko eztabaida-taldeetan lorturiko informazioarekin alderatu genituen ikasleek ikasgelan egindako jarduerak. Hiru ikertzailek kodetze gurutzatu itsu bat egin zuten.

\section{EMAITZAK}

Ikasleek beren informazio premiak definitzeko eta artikulatzeko duten gaitasunari dagokionez, egiaztatu dugu ezen aldez aurretik ezagutzen dituzten eta beren bizitzarekin erlaziona ditzaketen gaiak aukeratzen dituzten ikasleek zailtasun gutxiago dituztela informazioa bilatzeko: «Rocío: hobe da gutxi gorabehera ezaguna zaizun gai bat, ze horrela... horrela errazagoa egiten da» (GDAf). Ohituta ez dauden gaiekin lan eginez gero (etxegabetzeak, jihadismoa) ikasleek arazo gehiago dituzte informazioa bilatzeko prozesuan, berengandik hurbilago dituzten gaiak aukeratzen dituzten ikasleek baino (emakumearen egoera, landa-turismoa beren inguruetan, immigrazioa Nafarroan, ehizarako zaletasuna etab.). Bi ikaslek aldez aurretik idatzi dute zer-nolako informazioa bilatu nahi duten gaiari buruz; haietariko batek 16 bilaketa helburu ezarri ditu, eta gehiegizkoa suertatu da. Era berean, agerikoa izan da ikasle batzuek arazoak dituztela gaia aukeratzeko orduan. Ikasleek azaldu dute eskuarki irakasleek ematen dizkietela lanetarako gaiak, eta baliteke hori izatea arrazoia. Dena den, irakasleak proposaturiko gai (etxegabetzea) bati buruzko lan bat egin duen ikasle batek ez du interesik agertu; lana «erdi behartuta» egin duela adierazi du, eta zailtasun ugari izan ditu prozesuan zehar. Irakasleak ohartu dira ikasleek, salbuespenak salbuespen, zailtasunak dituztela informazio bilaketaren helburuak zehazteko eta egitura bat behar dutela horretarako: «Juan: arazoa da asko kostatzen zaiela nondik jo aukeratzea, zer interesatzen zaien gai horren barruan (...) asko kostatzen zaie lehen pauso hori, are bilatzen hastea baino gehiago» (ACG).

Informazio motari eta formatuei dagokienez, ikasleek gogo onez hartzen dute ikasgelan Internetera konektatuta lan egitea, eta liburuak edo irakasleen azalpenak baino informazio iturri azkar, erraz eta entretenigarriagotzat jotzen dute Internet: «Juan: [ikasgelan Internetekin lan egitea] itzela litzateke» (GDAi); «Lorea: [Internetekin] lanak askoz azkarrago egiten dituzu, eta batzuetan askoz hobeki ulertzen da liburu edo irakasle bat baino» (GDAi). Hala ere, ikasle batek ez du batere interesik agertu ikasgelako lanaren gainean, eta beste bik adierazi dute hobea eta errazagoa dela informazioa pertsona batengandik jasotzea: «Carolina: Interneten bilatzeak asko balio du, baina elkarrizketa egiteak ere bai, galdetzen ari zaren pertsonak ematen dizun informazioa osatuagoa delako Internetekoa baino» 
(GDAf). Ikasleak ohartzen dira Internetek arreta galtzea ekar dezakeela: «Carlos: arreta galtzeko arriskua dago, eta batezbestekoa jaitsiko da, ezin baituzu arretarik jarri eskolan eta aldi berean zure gauzetan aritu Interneten» (GDAf). Irakasleentzat, Internet dokumentatzeko beste iturri bat da, eta lehentasuna ematen diote informazio idatziari. Beldur dira ikasleek ez dutela informazio fidagarririk aurkituko, eta, hori dela eta, web-orrien URLak ematen dizkiete. Nolanahi ere, ikasle talde guztiek bilatzen dute informazioa irudi, bideo eta grafikoetan. Are gehiago, nahiago dute ikus-entzunezko informazioa: «Mikel: argazki batekin ez dugu ezer egiten; hobe da YouTubeko bideo bat ikusi, zer den jihadista bat, nolakoa den, eta kito (+ Fitxa berria; idatzi youtube.com bilaketa barran; + Ireki)» (TA).

Informazioa berreskuratzeko sistema egokiak hautatzeari eta bilaketa estrategia eraginkorrak praktikan jartzeari dagokienez, ikasleek onartzen dute batzuetan ez dutela aurkitzen bila dabiltzan informazioa: «Rocío: ez dakit, balio ez dizuten gauza asko agertzen zaizkizu, edo... zuk ere ez dakizu ongi zer jarri bilatu nahi duzun horri buruz, eta ordenagailuak ez du aurkitzen bila zabiltzan hori»(GDAf). Ikasleek diote Wikipedia dela berentzat informazioa bilatzeko iturri nagusietako bat eskolako lanetan. Eta hala ikusten da praktikan ere, talde guztiek erabili baitute entziklopedia birtuala gaiari buruzko informazioa erdiesteko. Horretaz gainera, denek erabiltzen dute YouTube plataforma bideoak bilatzeko, bai eta Googleren Irudiak ere, grafikoak ikusteko. Gaia ezaguna izanez gero, orrialde ezagunetara jotzen dute. Irakaslea, azaldu zienean nola erabili Googleren Bilaketa Aurreratuaren tresna, harrituta geratu zen ikusirik ikasle batzuek kolorearen arabera egiten zituztela bilaketak, berak ez baitzuen aukera hori ezagutzen. Ikasle eta irakasleek onartzen dute garrantzitsua dela informazioa bilatzen hasi aurretik ezagutza batzuk izatea, eta ikasle batzuek adierazi dute ez dutela interes bera jartzen gai pertsonaletan eta eskolako lanetan: «Daniel: zuretzat baldin bada, gehiago bilatzen duzu; eskolarako bada, lehenbizi ikusten duzunarekin geratuko zara segur aski»(GDAf). Irakasleek adierazi dute beharrezkoa dela ikasleei bilaketak egiten laguntzea URLak emanez: «Miguel: (...) nik uste dut ikasleak aldez aurretik ezer ez badaki gaiari buruz erronka ikaragarria dela (...) horregatik, informazio bilaketa zuzendu behar da: geuk bilatu behar ditugu berek informazioa bilatzeko orrialdeak; bestela, baso ilun bat bilakatzen zaie dena» (GDP).

Zer informazio behar duten birplanteatzeko eta bilaketarako estrategiak fintzeko orduan, ikasle batzuek diote aintzat hartzen dutela zein den beren bilaketaren helburua, informazioaren sarrera hautatu aurretik: «Rocío: hara! Hor hartu nahi duzu ostatu? Bilatuko dizut informazioa hor ostatu hartzeko, edo nola sortu ziren eta hori guztia? (Klik egiten du Bardeetako haitzulo etxeen SARRERAn: lasbardenas.com)» (TA). Ikasle gehienek bilaketak birformulatzen dituzte, geografikoki eta denboran mugatuta. Gaia oso ezaguna ez bada aldez aurretik, ikasleek zailtasun gehiago izango dituzte bilaketarako terminoak birformulatzeko. Horixe gertatu zaio jiha- 
dismoari buruzko informazioa bilatzeko soilik jihadismo gako hitza idatzi duen ikasleari. Ikasle batzuek adierazi dute lorturiko emaitzetatik abiatuta birformulatzen dituztela beren bilaketaren helburuak: «Carolina: gaiaz zertxobait gehiago dakizunean, Rocíok dioen bezala, ideia gehiago dauzkazu beste gauza batzuk bilatzeko» (GDAf). Irakasleek, oro har, uste dute ikasleek arazoak dituztela bilaketa espezifikoak egiteko.

Informazioa eta haren iturriak ebaluatzeko irizpideei dagokienez, ikasleek diote badakitela Interneten informazio faltsua dagoela, baina eskuarki ez dira ohartzen nor diren egileak edo zer aurreiritzi ideologiko dituen kontsultatutako informazioak: «Alba: nik ez diot erreparatzen (egileari). Bila zabiltzan informazioa badakar, zertarako jakin egilea nor den?»(GDAf). «Fermin: zer esan nahi duzu egilearen kontu horrekin?» (GDAf). Informazioaren ulergarritasuna ebaluatzean, ikasleek adierazi dute askotan zaila egiten zaiela Wikipediako informazioa ulertzea. «Ander: Wikipediak nazka ematen du (...) ez du ezer argitzen (...) kopiatu eta itsatsi, eta kito, baina ez du balio ezer ulertzeko, paragrafo berean hitz ulertezin pila bat jartzen dituztelako» (GDAf). Bere gaiari buruzko - ehiza - jarrera jakin bat duen ikasle bat ohartu da kontsultaturiko orri batek beraren ideien kontra egiten duela; orduan, besteek ez bezala, gogoeta egin du informazioaren xedeaz eta aurreiritzi ideologikoez. Gehienek balio handiagoa ematen diete informazio asko dakarten orriei. Informazioa gaur egungoa izatea ere ebaluatzen dute. Sinesgarritasunari dagokionez, ikasleak ohartzen dira irakasleek ez dutela konfiantzarik sareko informazioaren gainean: «Leire: ez dakizu seguru egiazkoa den ala ez. Hori dela eta, askotan, Interneten zerbait bilatzen duzu, eta gero irakasleek esaten dizute: «Hau Internetetik atera duzu, ez baita horrela». Fidatzen zara, eta gero konturatzen zara ezetz» (GDAi). Beste alde batetik, irakasleentzat mehatxu bat da sarea, «baso ilun bat», eta uste dute ikasleak ez direla gai sareko informazio egokia ebaluatzeko eta hautatzeko. Hortaz, web-orrietarako sarbidea mugatzen diete.

Ikasleek informazioa nola lantzen duten erreparatuz gero, ikasle batek dio Interneteko informazioa kopiatu eta itsatsi egiten duela berak eskuarki, nahiz batzuetan aldaketa txiki batzuk egin: «Carlos: orri bat hartu, eta kito, eta beharbada hitzen bat aldatu eta sinonimo bat jartzen dut, eta kito» (GDAi). «Rocío: orria osorik irakurri, garrantzitsuena ikusi, Worden kopiatu, eta horrela denekin»(GDAf). Irakasleek badakite hala jokatzen dutela, eta uste dute ontzat eman daitekeela baldin eta ikasleak gai badira testu kohesionatu bat idazteko eta informazioaren jatorria aitortzen badute. Ikasle gehienek titularrak eta epigrafeak irakurrita ateratzen dituzte testuen ideia nagusiak, eta, eskuarki, testu hasierako informazioa atxikitzen dute. Oro har, zailtasunak dituzte zenbait testu motatako informazioa erauzteko: grafikoak eta bideoak, adibidez. Hiru ikasle bikoteek arazoak dituzte grafikoak interpretatzeko; gehienetan, testuingururik gabe iristen dira haietara, Google Irudiak aukeraren bitartez. Bideoei dagokienez, batzuetan, azaleko informazioa bakarrik atxikitzen dute; adibidez, pertsonen itxurari dago- 
kiona: «Alba: (bideo bat ikusten ari dela) honek maltzur itxura dauka, hau gatzik gabekoa da, honek sasijakintsu hutsa ematen du» (TA). Ikasle bikoteetako bi eduki biolentoetan sartu dira, eta horrek emozionalki eragin die, batez ere gerra bateko muturreko indarkeriazko irudiek: «Mikel: hau ez da normala, aizu (klik egin du alboko BIDEOen zerrendan. «Soldados capturados e torturados por extremista do Estado Islámico» (gizon bat ageri da lurrean botata, gerritik gora biluzik, kolpez josita). Kendu egingo dut; ezin dut ikusi ere egin» (TA). Irakasleek uste dute ikasleei kosta egiten zaiela zenbait iturritako informazioa erlazionatzea eta laguntza behar dutela horretarako.

Bestalde, aztertu dugu ea nola baliozkotu duten bikoteetan informazioaren ulergarritasuna eta lana egin bitartean arreta galtzea. Ohartu gara ikasleak, bikoteka lan eginda ere, ez direla beti lankidetzan aritzen. Ikasleek uste dute bikoteka gehiago ikasten dela eta entretenigarriagoa dela. «Lorea: ikaskide batzuek besteek baino trikimailu gehiago dituzte, eta galdetzen diezu ea nola egin duten, ikusten duzu, eta egiten duzu» (GDAi). «Ander: bakarrik bazaude, azkarrago bukatu nahi duzu. Lehenbizi ikusten duzuna hartu, eta akabo. Ikaskide batekin bazaude, dibertigarriagoa da, eta denbora gehiago pasatu nahi duzu» (GDAf). Zenbait kasutan, interakzioaren bidez eraikitzen dute ezagutza; dena den, bikoteetako batean, ikasle batek bere gain hartu du lan guztia, bere bikotekidearen pasibotasunaren eta interes faltaren aurrean. Hirugarren bikotean, kideen lana desorekatua da, eta, batzuetan, elkarren lana boikotatzen dute. «Daniel: tontoa zara edo zer? Ergela zara. Ez dit ba pendrivea kendu... (...) hurrengoan, ederki larrutuko zaituztet» (TA).

\section{ONDORIOAK ETA EZTABAIDA}

Kasu azterketa bat denez, ondorioak ezin dira beste ikastetxeetara hedatu. Dena den, uste dugu ikerketa honek ekarpen handia egiten duela informazio digitala bilatzeko, ebaluatzeko eta hautatzeko jarduera didaktikoa ulertzeko, eta erabilgarria izan liteke IKTak Bigarren Hezkuntzako ikastetxeetan nola txertatu planifikatzeko.

\subsection{Ikasleen diskurtsoa eta praktikak}

Ikasle gehienek, beste ikerketa batzuetan ikusi den bezala (Gialamas, Nikolopoulou, Koutromanos, 2013), badute interesa eta nahiago dute ikasgelan Internetekin lan egin. Hala eta guztiz ere, ohartzen dira irakasleek ez dutela konfiantzarik sareko informazioan eta horrek legitimitatea kentzen diola Internet informazio iturri gisa erabiltzeari. Bestalde, ikasle batzuek diote Internet erabiltzean arreta gal daitekeela eta horrek kalte 
egiten diela beren emaitza akademikoei. Campos Martínezen ondorioekin bat eginez (2015), baliteke helduen iritziak eragina izatea ikuspegi horretan. Alde horretatik, ondoriozta daiteke irakasleek IKTen eta haien erabileraren inguruan dituzten usteek eragina dutela ikasleen praktikan eta pertzepzioan.

Ikasleek interes handia agertu dute ikasgelan Interneten lan egiteko, baina, praktikan, ikasle batzuk oso apatikoak dira informazioa bilatzeko orduan. Ikasleek berek onartzen dute ez dutela jarrera bera izaten interes pertsonaleko informazioa bilatzean eta eskolako lan baterako informazioa bilatzean. Ikasleen interesetatik eta haientzat zama emozional handia duten egiazko arazoetatik abiatuz gero, ikasleak gehiago inplikatzen dira lanean (Monereo \& Badia, 2012). Gainera, aurreko beste lan batzuekin bat eginez (Amadieu, Tricot \& Mariné, 2009; Coiro \& Dobler, 2007), badirudi bilaketa prozesua errazagoa dela gaia ezaguna bada aldez aurretik. Gaia ezezaguna denean (jihadismoa, etxegabetzeak), ikasleek arazoak dituzte orriak hautatzeko eta informazioa ebaluatzeko eta hautatzeko. Datu hori oso garrantzitsua da sareko informazioa bilatzearen gaia irakaskuntzan lantzeari begira; izan ere, bilaketetarako helburu eta testuinguruen arabera landu behar lirateke bilaketak egiteko estrategiak.

Informazioa alfabetizatzeko arau eta estandarren linealtasuna ez dator bat egiazko bilaketa prozesu batek dakarren konplexutasun, errekurtsibitate eta iterazioarekin. Ikasle gehienek ez dute informazioa bilatzeko helbururik ezartzen, eta aurkitutako emaitzetatik abiatzen dira bilaketak mugatzeko eta birdefinitzeko. Interesgarria litzateke jakitea zergatik daukaten ikasle batzuek gaitasun handiagoa bilaketa helburuak birdefinitzeko eta nola garatu litekeen konpetentzia metakognitibo bat informazioa bilatzeko, berrypicking eredura gerturatuz, eta ez estrategia lineal eta planifikatu bati jarraituz (Egaña, Zuberogoitia, Pavón, 2012).

Zenbait ikerketaren arabera, ikasleek Wikipedia erabiltzen dute eskuragarritasunagatik eta ulergarritasunagatik (Valverde-Crespo \& GonzálezSánchez, 2016), baina, ikerketa honetan, ikasleek adierazi dute erabiltzen dutela baina arazoak dituztela informazioa ulertzeko. Halaber, ohartu gara zailtasun handiak dituztela grafikoak ulertzeko eta ikus-entzunezko informazioa interpretatzeko eta eskuratzeko. Ez da erraza ikus-entzunezko informazioa idatzizkora ekartzea (Sevensma, 2013); horregatik, uste dugu beharrezkoa dela testu mota desberdinen arteko informazio transmediazioa ikasgelan lantzea (Smith, Kiili \& Kauppinen, 2016).

Gainera, ikasleei kosta egiten zaie egiletzaren eta plagioaren kontzeptuak ulertzea, baita kontsultaturiko informazioaren aurreiritzi ideologikoak ebaluatzea ere. Ezinbestekoa da ikasleek jarrera kritikoa izatea (Sancho Gil \& Padilla Petry, 2016) globosfera komunikatiboan, ez baita bereizten nork jasotzen duen informazioa, eta gero eta datu eta kutsadura informatibo gehiago baitago. Interneteko eta haren iturrietako informazioa ebaluatzea hezkuntzaren erronka handietako bat da. 


\subsection{Irakasleen diskurtsoa eta praktikak}

Irakasleek, oro har, uste dute Internet «baso ilun bat» dela eta ikasleak ez direla gai Interneten informazio egokia beren kasa bilatzeko; hori dela eta, gehienek kontsultatu beharreko URLak ematen dizkiete, edo orri jakin batzuetara bideratzen dituzte. Ondorioz, ikasleek ez dute ikasten bilaketa irekiak egiten. Komeniko litzateke irakasleek jardueraren kontrola progresiboki uztea ikasleen esku (Hernández Serrano \& Fuentes Agustí, 2011), jarrera kritikoa garatu dezaten eta sarean libre nabiga dezaten.

Frogatu da ikasleek laguntza eta egitura behar dituztela gaiak hautatzeko, bilaketarako helburuak ezartzeko eta birdefinitzeko, eta informazioa ebaluatzeko eta hautatzeko; irakasleak kontziente dira horretaz, baina ez dute beti lantzen. Garrantzitsua da irakasleei sinesmen pedagogikoei buruzko baliabideak eta prestakuntza ematea, beren zereginean txerta dezaten (Méndez Garrido \& Delgado García, 2016). Sinesmen horiek indartzeko, eraginkorragoa da epe luzeko prestakuntza ematea, lan testuinguruko prozesu iteratibo gisa antolatuta eta praktika komunitateetan eta irakasleen arteko lankidetzan babestuta.

Ikasgelan Internetekin lan egitean, zalantzan jartzen da irakaslea dela ezagutza duen bakarra, eta irakasleak beldur dira ikasgelaren kontrola galduko ote duten arazo teknikoengatik edo nola erantzun ez dakiten egoerak sortzeko arriskuagatik. Ikasgelan IKTekin lan egitean, ikasleek hartzen dute protagonismoa, eta irakasleen rola aldatzen da; irakasleek jakin behar dute zer muga dituzten, eta ikasleei berenak ikusarazi (Plaza de la Hoz, 2018). Hala, autoritate egitura horizontalagoetara iritsiko gara (Campos Martínez, 2015).

Azkenik, ohartu gara lan egoera desorekatuak sortzen direla ikasle taldeetan, are elkarren lana boikotatzen dutela; alegia, lankidetzan lan egiteko, ez da nahikoa taldean lan egitea. Frogatuta dago IKTekin egiten den lankidetzak ezagutza eraikitzen laguntzen duela (GarcíaValcárcel, Basilotta \& López, 2014), baina beharrezkoa da zenbait alderdi kontuan hartzea, hala nola taldeko kideen arteko hurbiltasuna, zereginaren zailtasuna parte hartzaileen rolei dagokienez eta irakasleen rol aktiboa lankidetzazko dinamika bat sortzeko (Avello-Martínez \& Marín, 2016).

Ikerketa honek kasu azterketen ohiko mugak ditu; hortaz, beharrezkoa da ikertzen segitzea, hezkuntzaren errealitate konplexua behar bezala ulertzea lor dezagun. Irakasleei beren lanean laguntzeko, garrantzitsua da zehatzago agertzea zer faktorek parte hartzen duten interakzio didaktikoan informazio digitala bilatzen, ebaluatzen eta hautatzen denean. Hezkuntza eredu baterantz egin behar dugu, eta eredu horrek kontuan hartu beharko luke ikasleek berezko zer premia eta praktika dituzten informazioa alfabetizatzea gero eta garrantzitsuagoa den gizarte honetan. 


\section{ERREFERENTZIAK}

Adell, Jordi; Castañeda, Linda (2012). Tecnologías emergentes, ¿pedagogías emergentes?. J. Hernandez, M. Penessi, D. Sobrino, A. Vazquez (coord.). Tendencias emergentes en educación con TIC. Barcelona: Associació Espiral, Educació i Tecnologia, 13-32.

Aguaded Gómez, J. I. \& Tirado Morueta, R. (2010). Ordenadores en los pupitres: informática y telemática en el proceso de enseñanza-aprendizaje. Pixel-Bit. Revista de Medios y Educación, 36, 5-28.

Altuna Urdin, J. (2011). Internet lehen hezkuntzan: zenbait galdera, erantzun eta proposamen. Tantak, 23(2), 7-31.

Amadieu, F.; Tricot, A. \& Mariné, C. (2009). Prior knowledge in learning from a non-linear electronic document: Disorientation and coherence of the reading sequences. Computers in Human Behavior, 25(2), 381-388. https://doi. org/10.1016/j.chb.2008.12.017

Area-Moreira, M.; Cepeda, O.; González Salamanca, D. \& Sanabria, A. (2010). Un análisis de las actividades didácticas con TIC en aulas de Educación Secundaria. Pixel-Bit: Revista de Medios y Educación, (38), 187-199.

Area-Moreira, M.; Hernández-Rivero, V. \& Sosa-Alonso, J.-J. (2016). Modelos de integración didáctica de las TIC en el aula. Comunicar, 47, 79-87. https://doi. org/10.3916/C47-2016-08

Area-Moreira, M. \& Pessoa, T. (2012). De lo sólido a lo líquido: las nuevas alfabetizaciones ante los cambios culturales de la Web 2.0. Comunicar, 19(38), 13-20. https://doi.org/10.3916/C38-2012-02-01

Association of College \& Research Libraries (ACRL). (2000). Information Literacy Competency Standards for Higher Education.

Avello-Martínez, R. \& Marín, V. I. (2016). La necesaria formación de los docentes en aprendizaje colaborativo. Profesorado. Revista de Currículum y Formación Del Profesorado, 20(3), 687-713.

Cambra, M. (2013). Investigar la interacción en las clases de lenguas. Cultura \& Educación, 25(4), 429-440.

Campos Martínez, J. A. (2015). Lo cotidiano (entre usos y resistencias) de las TIC en un aula de Educación Secundaria Obligatoria. Antropología Experimental, $15,567-580$.

Carretero, S., Vuorikari, R. \& Punie, Y. (2017). The digital competence framework for citizens. Luxenburgo: Publications Office of the European Union. https://doi.org/10.2760/38842

Coiro, J. \& Dobler, E. (2007). Exploring the online reading comprehension strategies used by sixth-grade skilled readers to search for and locate information on the Internet. Reading Research Quarterly, 42(2), 214-257. https://doi. org/10.1598/RRQ.42.2.2

Coll, C.; Mauri Majós, M. T. \& Onrubia Goñi, J. (2008). Análisis de los usos reales de las TIC en contextos educativos formales: una aproximación socio-cultural. Revista Electrónica de Investigación Educativa, 10(1), 1-18. https://doi org/ISSN 1607-4041

Dolz, J. \& Gagnon, R. (2010). El género textual, una herramienta didáctica para desarrollar el lenguaje oral y escrito. Lenguaje, 38(2), 497-527. 
Domingo Coscollola, M., y Fuentes Agustí, M. (2010). Innovación educativa: experimentar con las TIC y reflexionar sobre su uso. Pixel-Bit. Revista de Medios y Educación, (36), 171-180.

Eagleton, M.; Guinee, K. \& Langlais, K. (2003). Teaching Internet literacy strategies: The hero inquiry project. Voices From the Middle, 10(3), 28-35.

Egaña, T.; Zuberogoitia, A.; Pavón, A. \& Brazo, L. (2012). ¿Cómo evalúan la información de internet los estudiantes universitarios? Lo que dicen los estudiantes y sus profesores. Edutec: Revista Electrónica de Tecnología Educativa, 42, 1-11.

Egaña, T.; Zuberogoitia, A. \& Pavón, A. (2012). Nola bilatzen dute informazioa unibertsitate-ikasleek?: Mondragon Unibertsitateko Ikus-entzunezko ikasleen kasua. Tantak, 24(2), 53-76.

Ertmer, P. A. (2005). Teacher pedagogical beliefs: The final frontier in our quest for technology integration? Educational Technology Research and Development, 53(4), 25-39. https://doi.org/10.1007/BF02504683

Ertmer, P. A. \& Ottenbreit-Leftwich, A. T. (2010). Teacher technology change. Journal of Research on Technology in Education, 42(3), 255-284. https://doi. org/10.1080/15391523.2010.10782551

Fraga Varela, F. \& Gewerc Barujel, A. (2013). Creencias sobre Tecnología Educativa de profesorado en formación: un estudio de caso. Innovación Educativa, (23), 241-254.

García-Valcárcel, A.; Basilotta, V. \& López, C. (2014). Las TIC en el aprendizaje colaborativo en el aula de Primaria y Secundaria. [ICT in Collaborative Learning in the Classrooms of Primary]. Comunicar, 21(42), 1-8. https://doi.org/ http://dx.doi.org/10.3916/C42-2014-06

Gialamas, V.; Nikolopoulou, K. \& Koutromanos, G. (2013). Student teachers' perceptions about the impact of internet usage on their learning and jobs. Computers \& Education, 62, 1-7. https://doi.org/10.1016/J.COMPEDU.2012.10.012

Gil-Flores, J.; Rodríguez-Santero, J. \& Torres-Gordillo, J. J. (2017). Factors that explain the use of ICT in secondary-education classrooms: the role of teacher characteristics and school infrastructure. Computers in Human Behavior, 68, 441-449. https://doi.org/10.1016/j.chb.2016.11.057

Hatlevik, I. K. R. \& Hatlevik, O. E. (2018). Students' evaluation of digital information: The role teachers play and factors that influence variability in teacher behaviour. Computers in Human Behavior, 83, 56-63. https://doi. org/10.1016/j.chb.2018.01.022

Hernández Serrano, M. J. \& Fuentes Agustí, M. (2011). Aprender a informarse en la red: ¿son los estudiantes eficientes buscando y seleccionando información? TESI, 12(1), 47-78.

Hew, K. F. \& Brush, T. (2007). Integrating technology into K-12 teaching and learning: Current knowledge gaps and recommendations for future research. Educational Technology Research and Development, 55(3), 223-252. https:// doi.org/10.1007/s11423-006-9022-5

Kim, C.; Kim, M. K.; Lee, C.; Spector, J. M. \& Demeester, K. (2013). Teacher beliefs and technology integration. Teaching and Teacher Education, 29(1), 76-85. https://doi.org/10.1016/j.tate.2012.08.005

Kim, K.-S. \& Sin, S.-C. J. (2011). Selecting quality sources: Bridging the gap between the perception and use of information sources. Journal of Information Science, 37(2), 178-188. 
Kuiper, E.; Volman, M. \& Terwel, J. (2009). Developing Web literacy in collaborative inquiry activities. Computers \& Education, 52(3), 668-680. https://doi. org/10.1016/j.compedu.2008.11.010

Lawrence, J. E. \& Usman, A. T. (2018). Factors that influence teachers' adoption and integration of ICT in teaching/learning process. Educational Media International, 1-27. https://doi.org/10.1080/09523987.2018.1439712

Mama, M. \& Hennessy, S. (2013). Developing a typology of teacher beliefs and practices concerning classroom use of ICT. Computers \& Education, 68, 380387. https://doi.org/10.1016/j.compedu.2013.05.022

Méndez Garrido, J. M. \& Delgado García, M. (2016). Las TIC en centros de Educación Primaria y Secundaria de Andalucía. Un estudio de casos a partir de buenas prácticas. Digital Education Review, 29, 134-165.

Monereo, C. \& Badia, A. (2012). La competencia informacional desde una perspectiva psicoeducativa: enseñanza basada en la resolución de problemas prototípicos y emergentes. Revista Española de Documentación Científica, 35 (Monográfico), 75-99.

Moreno Mínguez, A. (2013). Informe Juventud en España 2012. Madrid.

Plaza De La Hoz, J. (2018). Autoridad docente y Nuevas Tecnologías: cambios, retos y oportunidades. Revista Complutense de Educación, 29(1), 269-286. https://doi.org/10.5209/RCED.52281

Pow, J. \& Li, C. S. (2015). The effect of students' perceptions of Internet information quality on their use of Internet information in inquiry-based learning. Australasian Journal of Educational Technology, 31(4), 439-457.

Rodríguez Ruiz, Ó. (2005). La triangulación como estrategia de investigación en Ciencias Sociales. Revista de Investigación En Gestión de La Innovación y Tecnología, 31.

Ros, I. \& Ferradas, M. (2013). Teknologia berrien aplikazioa bigarren hezkuntzako heziketa fisikoan. Tantak, 25(1), 27-46.

Sancho Gil, J. M. \& Padilla Petry, P. (2016). Promoting digital competence in secondary education: are schools there? Insights from a a case study. Journal of New Approaches in Educational Research, 6(1), 57-63. https://doi. org/10.7821/naer.2016.1.157

Sancho Gil, J. M. \& Hernández, F. (2018). La profesión docente en la era del exceso de información y la falta de sentido. RED. Revista de Educación a Distancia, 56,4 .

Sevensma, K. (2013). Expanding conceptualizations of online reading comprehension to support at-risk readers. In International Society of Technology in Education's 34th Annual Convention. San Antonio, Texas.

Smith, B. E.; Kiili, C. \& Kauppinen, M. (2016). Transmediating argumentation: Students composing across written essays and digital videos in higher education. Computers and Education, 102. https://doi.org/10.1016/j. compedu.2016.08.003

Thereau, J. (2010). Les entretiens d'autoconfrontation et de remise en situation par les traces matérielles et le programme de recherche «cours d'action». Revue d'anthropologie Des Connaissances, 4(2), 287-322.

Tirado-Morueta, R. \& Aguaded-Gómez, J. I. (2014). Influencias de las creencias del profesorado sobre el uso de la tecnología en el aula. Revista de Educacion, 363, 230-255. https://doi.org/10.4438/1988-592X-RE-2012-363-179 
Tondeur, J.; Van Braak, J.; Ertmer, P. A. \& Ottenbreit-Leftwich, A. (2017). Understanding the relationship between teachers' pedagogical beliefs and technology use in education: a systematic review of qualitative evidence. $E d u$ cational Technology Research and Development, 65(3), 555-575. https://doi. org/10.1007/s11423-016-9481-2

Unesco. (2005). Towards knowledge societies. Paris: Unesco.

Valverde-Crespo, D. \& González-Sánchez, J. (2016). Búsqueda y selección de información en recursos digitales: Percepciones de alumnos de Física y Química de Educación Secundaria Obligatoria y Bachillerato sobre Wikipedia. Revista Eureka Sobre Enseñanza y Divulgación de Las Ciencias, 13(1), 67-83.

Watkins, R.; Engel, L. C. \& Hastedt, D. (2015). Is the «Net Generation» ready for digital citizenship? Perspectives from the IEA International Computer and Information Literacy Study 2013. Amsterdam: IEA. 